\title{
Developing a Design of an Analog Electronics Practice Instruction as an Effort to Improve the Professionalism of Prospective Vocational Teachers
}

\author{
Purnamawati \\ State University of Makassar, FT Parangtambung Campus, Makassar, INDONESIA \\ tari_purnamawati@yahoo.com
}

\begin{abstract}
This research aims at producing a design of an analog electronics practice instruction as an effort to improve the professionalism of prospective vocational teachers. This research is a development research employing the modified instructional development model of Thiagarajan. The results are as: Firstly, the design of an analog electronics practice instruction fulfills the criteria of good quality. It is found that: (1) the instructional design is valid; (2) the competency of the prospective vocational teachers in managing the instruction is good enough; (3) activities are effective; (4) responses towards the instructional components are positive; and (5) the practical assessment fulfills the criteria. Secondly, the results of analog electronic practices achieved by the prospective vocational teachers show that (1) improving the competence an analog electronics practice; (2) the competency in managing an instruction is effective; (3) the practical activities are implemented effectively; and (4) the responses towards the instruction is positive.
\end{abstract}

Index Terms - analog electronics practices, instructional designs, professional teachers.

\section{Introduction}

This research aims at producing a design of an analog electronics practice learning of learning at Electronic Engineering Education Department (EEED) Faculty of Engineering (here after FT) of UNM Curriculum Based Competence (CBC) in order to improve the professionalism of vocational school prospective teachers individually. The Analog Electronic Practice subject is an initial device to increase the vocational prospective teachers' motivation and competence in electronic practice at EEED department in Computer and Telecomunication Electronic Engineering concentration. Therefore, after learning the analog electronics practice learning, vocational school prospective teachers are expected to know how to string, analyze and apply a series of electronics. In addition, this subject also functions as a basic skill to learn the next subject. Especially in practical subjects, the understanding of electronic principles will help the teachers to understand the concept of electronic application [1]. In addition, analog electronics practice learning is also as a subject concentration in computer and telecomunication electronic engineeringconcept of electronic application [1]. In addition, analog electronics practice learning is also as a subject concentration in computer and telecomunication electronic engineering.

In an attempt to support the learning process of analog electronics practice learning, the teacher teams for this subject at the first and last semester have to make an internal evaluation of practice learning devices; lab work tutorials/handout (jobsheet), learning materials, learning media, and learning evaluation used to complete the learning content. The internal evaluation result is followed up through some changes of lab working devices. This is important because the teachers do not only learn a series of electronics monotonously but also software visualisation through computer in analyzing the series of electronics. In addition, to improve the quality of learning process, the cooperation with some industries related to the subject content in the implementation of lab working process is already done.

Practical works use an approach that helps the university students to develop their ability to plan, design, practice, measure, analyze, and present the lab work result [2]. This approach affects that real world environment is prepared for the students to learn the skills which will be used in a concrete world, so that activities are usually in project forms. Through this approach, the capability will be more effective because it is not restricted by declarative knowledge or skills of soffware programming.

Learning in a laboratory is basically a structured experimental learning. This learning type is implemented if a direct experience with hands on activities is intended or essential to learn special skills and get certain comprehension [3]. In its development appreciation toward experimental learning type, lab work is utilized more intensively and widely in teaching. As a result, in education, particularly in learning and teaching process, a laboratory is used to provide students with skills and specific experience as been stated in the applied curriculum.

Limitation of the aims of practical work in engineering education. Those are improving (1) psycomotorict ability; (2) imajinative skill to design, construct tools, arrange protocol of lab working activity; (3) capablilty of using instruments; (4) capablilty of measuring, observing, collecting data, interpretating, and explaining the practical work result; (5) writing ability; provide arguments or express opinion in a structured and systematic manner; (6) autonomous learning and critical thinking ability; (7) confidence to own abilities; (8) strengthen beliefs and the truth of a theory; (9) ability to work in pairs and appreciate each other; and (10) attitude and understanding of scientific meteodology. These components are very important to know by the prospective teachers of vocational schools in order to prepare themselves before learning the steps of electronic practice learning, especially analog electronics practice learning [4].

Steps of practice learning that have to be understood for the attaintment of learning objectives, that is based on the motoric skills on the implemented practice learning, are: (1) steps or working procedure; (2) technique in using working tools (masinal/manual); (3) working attitude (individual/group); (4) using source information; (5) ability in working analysis; (6) accuracy; (7) neatness; (8) 
cleanliness; (9) rapidity and (10) working safety. Based on some essential components in practice learning stated previously, it can be identified a number of skills that have to be supplied in practice learning [5]. Furthermore, it will be easier for the lecturers to further evaluation. The research result of [6] shows that to implement electronic industry learning with construvistic approach, suitable learning devices are needed. Therefore, good learning devices must be developed for microprocessor course; those are lesson plan, jobsheet/lab working tutorials, teaching book, and a test. Moreover, in the practicum activities of learning industrial electronics, the effective steps that have to be taken into account are planning, design of learning, and implementation of instruction, in which these steps are different from learning theory. The strategies of practical learning based on competence and production-oriented are planning, implementation, and evaluation [7].

Eventhough many efforts have been done, problems still exist in learning process of analog electronics practice learning, that is the low ability of the prospective teachers of vocational schools in understanding the materials of practical works, lack of comprehension about steps of lab work in jobsheet, and the low ability of doing lab work. In details, those conditions are marked by indicators. Firstly, the prospective teachers of vocational school are not able to understand and use the principles of electronics, particularly to understand the definition of SCR charasteristics about input and emiter configuration as well as its output, filter, hibrid parameter, amplifier, and feedback. Secondly, the teachers perform the inability to answer electronic questions which ask for their synthesis process and analyze dificult series of electronics. Thirdly, the interview result of prospective teachers that asks for their opinion about the jobsheet electronic practical analog shows that in general the students are difficult in understanding the explanation of lab work handouts. The handouts do not explain the steps of the practices precisely; the sentences are too general and ambiguous. Based on this first analysis, an appropriate approach is needed in designing analog electronics practice learning so that the effectiveness of learning can be reached succesfully along with the improvement of prospective teachers' professional ability of electronic engineering department.

Other factors assumed as causes of the problems above are: (1) the teachers do not have ability to reason by using the accurate principles of electronic analog in analyzing definitions, theorems or principles of a scheme; (2) in general the teachers do not have good ability in analyzing a series of electronics. Process of analyzing a series of electronics are: counting, visualing, comparing, estimating, measuring, modeling, reasoning, connecting, representing, and using tools; (3) assessment is not completed in a systematic manner, and (4) they commonly are still in doubt to share their academic difficulties to their lecturers during practice learning process. In addition, prospective teachers hesitate to ask for help, eventhough the lecturers had given chances both formally and informally.

Factors that cause the inability of prospective teachers in understanding the materials of analog electronics practice learning as stated above have to be solved to improve the teachers' ability for further learning process. Moreover, it is also expected that they successfully teach themselves with qualified result. Therefore, developing analog electronics practice learning learning design must be done wich involves the teachers' skills at electronic engineering department of EEED in order to (1) streamline the learning process resulting in an appropriate learning design which suits with the teachers' characteristics, (2) providing prospective teachers that are able to plan, string and analyze a series of electronics and (3) prospective teachers who posess knowledge, attitude and qualified skills.

Based on the introduction stated previously, a research question is formulated: how are the process and result of design development of analog electronics practice learning at electronic engineering of FT UNM in order to improve the professionalism of prospective teachers of vocational school individually?

\section{Research Methodology}

\section{a. Research design}

The type of this study is research and development of analog electronics practice learning at electronic engineering of EEED FT UNM in an attempt to improve the professionalism of prospective teachers. This research and development is production-oriented, in which its elaboration process is described as accurate as possible to get a qualified learning design.

\section{b. Research Subject}

Based on the needs of this learning design, the subjects of this research were prospective teachers who were following the course of electronic practice of analog, in the 2012/2013 academic year. The development of this learning design in this research used "4-D model" [8]. The steps of the elaboration are as follows;

1) Defining stage

Defining stage aims at specifying and defining terms needed in learning. Activities carried out in this stage are: pre and post analysis, teacher analysis, concept/theory analysis, task analysis, and specifying the learning objectives.

2) Planning Stage

Planning stage aims at producing a draft design of Analog Electronics Practice learning. The results obtained are so-called prototype 1 (prototype material) which includes: lesson plans, practical guide, teaching materials, Jobsheet, and assessment of learning practices of analog electronics. Activities implemented at the design stage, namely: media selection, the selection of the format, and the initial design.

3) Stage of development

Stage of development aims at producing instructional design practices analog electronics with good quality. The criteria used to declare that this design has good quality, only if it meets the validity and effectiveness indicators. Activities undertaken, namely: validation experts and practitioners, and test development. In this schematic design development procedure is to obtain a good quality of learning/intructional design.

\section{c.Instruments and Data Collection Techniques}

The instruments referred to this section aims at measuring the validity and effectiveness of the instructional design of Analog Electronics Practice. Therefore, the instruments used are: (1) validation sheet, (2) observation of activity sheets of prospective teachers, (3) observation sheet lecturer ability to manage learning, (4) teacher candidate questionnaire responses to the practice of instructional design of Electronics Analog, and (5) Analog Electronic Learning Practice (AELP). 


\section{d. Data analysis}

The descriptive statistics is a method used to collect, process, and present the data in the form of figures, tables, or graphs, and some basic statistics such as mean, median, mode, and variance [9]. Therefore, data analysis of this research used descriptive statistical analysis. The analysis of these data are data analysis of validation outcome, data analysis of prospective teachers activity, data analysis of lecturers in managing the learning process, data analysis of the prospective teachers' response toward the design of learning package of Electronics practices, and data analysis of learning achievement of Analog Electronics Practice.

\section{Results and Discussion}

\section{Description of Learning Design Development Results}

Instructional designs developed in this study are: Unit Event Class (UEC) or Contract Lectures (CL), practical guide, jobsheet, books teaching materials, and achievement test. Therefore, based on the design development phases of Analog Electronics Practice learning in this study, the researcher used a modified model of Thiagarajan.

\section{a. Description of Defining Stage}

Firstly, curriculum conducted in EEED is curriculum based compotence by the views of constructivism. Curriculum based compotence is not analog electronics practice learning skill-oriented and problem solving of electronics, but prospective teachers were supplied with the ability to think logically, analytically, systematically, critically, creatively, as well as the ability to cooperate. In addition, the CBC also stressed the importance of using a problem based on the situation (contextual problems) in initiating the activities of practical learning of analog electronics.

Based on the interview result of a lecturer who teached analog electronics practice at odd semester 2012/2013, it was found that the skills of analog electronics, namely; a simple design and measurement of Operational Amplifier (Op-Amp), are difficult topics for the prospective teachers. As a result, there is a tendency of prospective teachers to simply predict without doing circuit analysis. Therefore, students often found difficulties doing the excercises related to the topic of a series of Op-Amp. Furthermore, it is also known that the learning that has been done by the lecturers these days does not involve prospective teachers. Lecturers are still using conventional learning patterns, which only explain the concept or procedure with question and answer; give some examples of questions/tests. This affects students for not being accustomed to build up knowledge or a way to resolve the problems found.

One of the analog electronics practice learning approaches that focusing on activating prospective teachers and emphasizing the importance of using contextual problems are: (a) students-centered/prospective-centered learning approach; (b) Prospective teachers are easy to learn the course materiasl of analog electronics through EWB software in analyzing the circuit; (c) Prospective teachers can apply the materials they have learned both in doing the excercises and solving daily problems; and (d) can improve the learning outcomes of prospective teacher.

To carry out the analog electronics practice learning with constructivism approach, an appropriate learning design is required. Therefore, it is necessary to develop a good instructional design to such topics like Op-Amp circuits, namely UEC, practical guide, Jobsheet, books teaching materials, and achievement test.

Secondly, the characteristics of prospective teachers 2012/2013 academic year examined based on their cognitive development, academic skills, knowledge background, and socioeconomic backgrounds. Flavell [10] wrote that children at the formal operational stage have four characteristics, namely: deductive hypothesis, proportional thinking, combinatorial thinking, and reflexive thinking. Therefore, based on the second characteristics, the selection problem that will be used to build a concept is not relied on to concrete problems. This agrees with the definition of OpAmp circuit topic.

Thirdly, material analysis aims at identifying the main parts of that will be studied by prospective teachers on the course material of measurement and analysis of transistor amplifier circuits and IC components.

Fourthly, the expected skills that have to be mastered by the prospective teachers in learning analog electronics.

Fifthly, the specification of learning objectives is done by outlining the indicators of learning outcome achivement into more specific indicators based on the analysis of concepts and task analysis.

\section{b. Description of designing stage (Design)}

Firstly, instructional media needed in the implementation of learning practices analog electronics include: UEC, practical guide, Jobsheet, books teaching materials, and achievement test. In addition, some of the helpful learning tools are required such as practical tools, and so on.

Secondly, Selection format for learning designs was adjusted to the principles, characteristics and procedures of analog electronics practice learning. In teaching units, the standards of competence, basic competence, indicators, subject matter, the material prerequisites, media, learning resources, learning models and strategies, as well as learning activities are listed in. Learning activities consist of opening, main activities, and closing activities. Practical guide listed: Chapter I: Introduction, Chapter II Implementation Practice, Chapter III Technical Guidelines and Rules, Chapter IV Closing; jobsheet listed: goals, tools and materials, supporting theory, and the experimental steps. The book contains teaching materials and achievement test result which loads completion instructions and questions.

Thirdly, at this stage the initial draft of contract lectures, practical guide, and book teaching materials, jobsheet, and achievement test for 4 meetings are procuded. All the results of the design phase are called Draft I.

\section{c. Description of Development Stage (Develop)}

Based on the results obtained in the first draft, development was conducted in the next stage. The development steps are as follows.

1. The results of the validation

The results of the validation were performed by 10 (ten) persons; 5 (five) persons were prospective teachers of EEED who have programmed this course and 5 (five) analog electronics lecturer both theory and practice. Assessment conducted by the validators includes some indicators: the format, language, and the content of the lesson plan. On the other hand, the researchers referred to the results of discussions by following suggestions from the validators. Validation results show that the developed learning design including criteria very has been well-designed and can be 
used with few revisions, so that this revised instructional design was only based on the validators' suggestions.

\section{Experiment of Analog Electronic Learning Practice Design}

Experiment aims at improving the instructional design before learning design used in the laboratory. This test was running for 4 (four) meetings in accordance with the CL. Classes chosen as the experiment class was a prospective teacher in academic year 2012-2013.

In the learning process, the prospective teachers are grouped into 5 (five) groups with mix ability, so that there were six (6) people in one group in which one group consisted of teachers with highest ability, prospective teachers with moderate ability, and prospective teachers with lowest ability. Grouping prospective teachers into the top, moderate, and low ability were based on their daily test result and their final scores before practice. Thus, it can be said that the ability of each group are relatively similar. In the other words, based on the scores of analog electronics practice is homogeneous, but the scores of theirs in each group were heterogenous. In addition, interviews were conducted as well as consulting with faculty to anticipate a mismatch among teacher candidates, so that the interaction among them when learning in a group was not disturbed.

Experiment was followed by two (2) observers observing the activities of prospective teachers and lecturers' ability to manage learning. Researchers also served as a general observer, who observed the learning process. Observations on the prospective teachers' activities were conducted toward one group, for 4 (four) meetings of the implementation of learning. This was done for the following reasons: (a) one group is considered best to represent other groups because the ability of each group are relatively similar; and (b) an observer is impossible to observe accurately to more than one group because the observations carried out continuously every three minutes (plus one minute to note) during the process.

Observations on the prospective teachers' activities were conducted on six (6) teachers, for 4 (four) times of the implementation of learning (4 UEC), 2 (two) members of the group, two (2) members of the group were and 2 (two) those of the low group. The data obtained during the experiment were analyzed, and the result was used as a material consideration to revise the instructional design. After being revised, the the learning design result was experimented through several stages. Data obtained from the tests consisted of prospective teachers' activities; professors' capabilities in managing the learning process, and the data of prospective teachers' response.

\section{a. The observation result of prospective teachers during the learning activity}

The prospective teachers' activity was observed by two observers. The observation was conducted during the learning process in which the learning began with preliminary activities, core, and evaluation. It was carried out during the learning process and the results show that in each UEC the activity of prospective teachers was classified as effective learning category. Therefore, the percentage of activity for each category of prospective teachers observed in each meeting was at the effective learning, so the learning design is not revised based on the results of observations. The data are clearly described in the following Table 1.
TABLE 1. THE PROSPECTIVE TEACHERS’ ACTIVITIES DURING THE LEARNING PROCESS

\begin{tabular}{|c|c|c|c|c|c|}
\hline \multirow{2}{*}{$\begin{array}{l}\text { Observation } \\
\text { Category }\end{array}$} & \multicolumn{4}{|c|}{ Percent $(\%)$} & \multirow{2}{*}{$\begin{array}{l}\text { Range } \\
\text { score } \\
(\%)\end{array}$} \\
\hline & RP 1 & $\mathrm{RP} 2$ & RP 3 & $\mathrm{RP} 4$ & \\
\hline $\begin{array}{l}\text { Paying } \\
\text { attention/listening to } \\
\text { the lecturers' and } \\
\text { friends' explanation }\end{array}$ & 18.48 & 18.48 & 11.96 & 17.39 & $9-19$ \\
\hline $\begin{array}{l}\text { Reading/understandi } \\
\text { ng problems at the } \\
\text { jobsheet }\end{array}$ & 14.13 & 15.22 & 13.04 & 7.61 & $6-16$ \\
\hline $\begin{array}{l}\text { Solving } \\
\text { problems/finding } \\
\text { solutions and answer } \\
\text { for the questions at } \\
\text { the jobsheet }\end{array}$ & 34.78 & 33.70 & 36.96 & 39.13 & $33-43$ \\
\hline $\begin{array}{l}\text { Discussing/asking } \\
\text { friends or lectures }\end{array}$ & 19.57 & 23.91 & 28.26 & 22.83 & $19-29$ \\
\hline Making conclusion & 13.04 & 8.70 & 9.78 & 13.04 & $8-18$ \\
\hline $\begin{array}{l}\text { Behaviour which is } \\
\text { irrelevant to } \mathrm{KBM}\end{array}$ & 0 & 0 & 0 & 0 & $0-5$ \\
\hline
\end{tabular}

UEC contains some indicators of prospective teachers' activities at effective learning category. The percentage of teachers' activity for each observation category and each meeting are at effective learning category, so the learning design is not revised based on the results of observations result of prospective teachers' activity.

\section{$b$. The evaluation results of the lecturer's ability to manage learning}

The assessment results of leactures' ability to manage learning can be concluded that the lecturer's ability to manage learning at the first meeting until the third meeting were categorized as "Moderate" $(2.80 \leq \mathrm{TKG} \leq 3.40)$. At the fourth meeting the lecturer's ability to manage learning reached the level of "good $(3.40 \leq \mathrm{TKG} \leq 4.20)$. Furthermore, when viewed from each aspect of the lecturers' ability, some of them were still classified as "poor" (value 2). It was seen from several components, namely: (1) Ability to motivate prospective teachers and communicate the learning goals; (2) The ability to connect with the lesson when the previous lesson or discuss jobsheet; (3) Ability to confirm the important things /essential thing related to learning; and (4) Ability to convey the title of next sub material/assigning tasks to prospective teachers and close the lesson.

This bad assessment in the first meeting is understandable because the lecturer was still unfamiliar and still adjusting to the learning undertaken. To anticipate this case, after completing the learning activities at the first meeting, the researcher discussed with the lecturer's partners, so that at the next meeting the lecturer performed better. Therefore, the ability of lecturers to manage learning can be said "effective".

\section{c.The results of the questionnaire/prospective teachers' response \\ Observation of the lecturer's ability to manage the} learning was done during the learning process and the result of the prospective teachers' response through questionnaire shows that after participating in learning all aspects of the 
response is above $80 \%$. However, for the new components about whether the subject matter percentage of positive responses teacher candidates is less than $80 \%$. This is likely caused because the prospective teachers felt the material being taught is no longer new, because it has ever been taught before. But the overall average response for each aspect of teacher candidates is above $80 \%$. This shows that every aspect was responded positively so that the learning device is not revised based on prospective teachers' responses. The data are clearly described in the following figure;

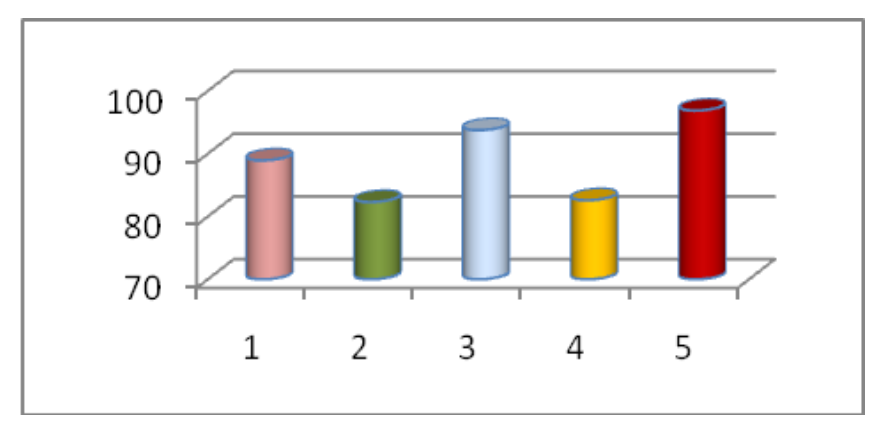

Figure 1. Histogram Table of Prospective Teachers' Responses towards Design Practice Learning Analog Electronics

Specification:

1.Interest in the lecture component

2.Learning Component Recency

3.Interests of prospective teachers in attending the class

4.Understanding the Language of learning design

5. The interest towards writing, illustration /pictures, and layout of pictures

\section{d. Experiment result of Achievement test}

Experiment of achievement test aimed at obtaining data regarding the validity of the test, reliability of the test, and sensitivity of the test item. All the three of these indicators are to determine whether a test developed need to be revised or not. The results of the validity, reliability, and sensitivity analysis of the test can be seen as follows;

1) Validity

Based on the formula of the product moment correlation, the degree of validity of each test item obtained was at high category. Thus, all of the test items were valid so that the test was properly used without revision.

2) Reliability

The results of the analysis showed that the reliability coefficient is $\alpha=0.803$. This means that the reliability of the test developed was categorized as "very high". As a result, the test is reliable and can be used without revision to measure the level of the teacher candidates' mastery of Analog Electronics Practice subject.

\section{3) Sensitivity}

The sensitivity of each test item is sensitive towards learning. Thus, all items of the test are sensitive so that it deserves to be used without revision.

As described earlier in the experiment phase, the results obtained are: (1) prospective teachers' activity activity effectively meets the criteria of prospective teachers ideal time tolerance limits; (2) The ability of the lecturer to manage learning is effective; (3) The responses of prospective teachers are positive; and (4) Test of achivement of each item is reliable, valid, and sensitive. Based on the criteria of good teaching devices, at this experiment stage it has produced a good quality of Analog Electronics practice learning design. This instructional design is completed with
UEC, practical guide, jobsheet, books teaching materials, and achievement test.

Based on the results of the validation of expert studies, instructional design and test results of individuals, small group testing and field trials of the developed learning model, it shows that instructional design is able to provide value-added, and effective in improving the competence of prospective teachers. The learning process is based on mastery and understanding of materials and practices with regard to the expected competencies. Likewise, from a small group of test results and field also shows that the independence of prospective teachers is an attitude that is formed as a result of careful design of the learning process. In accordance with the opinion of exposure [11] stated that the teaching model in the form of examples of knowledge which aims to assist students in obtaining the information, ideas, skills, values, ways of thinking and a way of expressing their ideas, as well as teach students ways to learning.

Furthermore, [12] in his article concludes that the modelspecific approach to teaching has four characteristics, namely: (1) help teachers gain an understanding in developing critical thinking skills; (2) includes a series of specific measures intended to achieve the objectives; (3) based on the theory of learning; and (4) supported by the theory of motivation. [13] in his study discusses the concept of ability and build 'expert learners' providing innovative foundation for end users in computer education. Further results of the study [14] found that the students said to have technical competence, if the students have the ability of vocational skills, also has a problem-solving, innovation, and adaptation skills. According to [15] learning model is a set of specific teaching principles, integrated and practical, that is used by teachers implicitly or eksplesitly about effective teaching conception, in which these models and manual contains special materials for teachers to use in doing their teaching.

\section{Conclusions}

This section presents some conclusions related to the development of instructional design;

a) By using 4-D models that have been modified, it has produced instructional design practices analog electronics that meet criteria good device/valid. This is shown by: (1) the device is declared "valid" by validator; (2) the ability to manage learning by the lecturer are categorized as: fairly good; (3) the activity of prospective teachers is effective; (4) the prospective teachers' response to learning components are positive; and (5) Learning Test Results are valid, reliable and sensitive. Therefore, the learning device consists of: (1) UEC, (2) practical guide, (3) jobsheet, (4) books teaching materials, and (5) achievement test.

b) Analog Electronics Practice-based Learning showed the following results: (1) the lecturer's ability to manage learning is effective; (2) the activity of prospective teachers is effective; and (3) the prospective teachers' response to learning components are positive suggestion.

c) Based on these research results, the design of Analog Electronics Practice learning applied to the learning activities provide some important things to note. 


\section{Acknowledgment}

On this occasion, I would like to thank all parties for their assistance during conducting this research. Firstly, the first thanks goes to the Chairman of the UNM Research Center for having funded through this research through PNBP. Secondly, thanks are also adressed to the lecturers of Analog Electronics Practice subject as a teacher model during the study period. Thirdly, thanks to Rector of UNM, Dean of Faculty of Engineering of UNM, peers in the FGD, the observer, lecturer model, prospective vocational teachers, and all those who have helped in the implementation of this research. Finally, I hope this research is helpful in improving the quality of learning, especially for Analog Electronics Practice course.

\section{Reference}

[1] Silabus Matakulian Praktik Elektronika Analog PTA (2009).

[2] Williams, Laurie., \& Upchurch, Richard. Extreme programming for soft-ware engineering education?. 2001. pp.3. Available: http://citeseerx.ist.psu.edu/viewdoc/download?

doi=10.1.1.161.8232\&rep=rep1\&type=pdf

[3] Sonhadji, Ahmad. Laboratorium sebagai basis pendidikan teknik di perguruan tinggi. Pidato Pengukuhan Guru Besar dalam Bidang Ilmu Manajemen Pendidikan dan Pelatihan Teknik. Malang: Universitas Negeri Malang.2002.

[4] Djoni Prawira Raharja. (2008). Strategi dan Teknik Belajar dari Kegiatan Laboratorium. [Online]. Available: http://www.unhas.ac.id .

[5] Dedy Suryadi \& Ahmad Anwar Yusa. (2009, April). Model Pembelajaran Berbasis Produksi Dengan Pendekatan Asesmen Portofolio Pada Perkuliahan Praktik Kerja Bangunan. Jurnal Penelitian. [Online]. 9(1).pp. 4.Available:http http://jurnal.upi.edu/file/Dedy_Suryadi.pdf.

[6] Mantasia \& Purnamawati. (2010, Nopember). Pengembangan perangkat pembelajaran bidang keahlian elektronika Industri di Sekolah Menengah Kejuruan (SMK) Negeri 5 Makassar. Laporan Penelitian PNBP UNM Makassar, tidak dipublikasikan.

[7] R. Mursid. (2013, Pebruari). Pengembangan model pengembangkan praktik berbasis kompetensi berorientasi produksi. Cakrawala Pendidikan. 32(1), pp. 27-40.

[8] Thiagarajan, Sivasailam, Sammel, Dorothy \& Sommel, Melvyn I. Instructional Development for Training Teachers of Exceptional Children. A Sourcebook. Minnepolis: Indiana University. 1974. [Online]. Available: http://files.eric.ed.gov/fulltext/ED090725.pdf.

[9] Muhammad Arif Tiro. Statistik Terapan untuk Ilmu Ekonomi dan Sosial. Cetakan keempat, edisi Kedua. Makassar: Andira Publisher.2010.

[10] Ratna Wilis Dahar.Teori-teori Belajar dan Pembelajaran. Bandung: Jakarta: Erlangga. 2011.

[11] Joyce, B., Weil, M., \& Calhoun, E. Models of teaching, $7^{\text {th }}$ ed. Boston: Pearson Education, Inc. 2004, pp. 7.

[12] Rüütmann, Tiia., \& Vanaveski, Jüri. (2009). Effective strategies and models for teaching thinking skills and capitalizing deep understanding in engineering education, Problems of Education In the 21st century, [Online]. 17, pp 176-187. [Online]. Available: http://oaji.net/articles/2014/457-1399915280.pdf.

[13] Phelps, Renata., Ellis, Allan., \& Hase, Stewart. (2001). The role of metacognitive and reflective learning processes in developing capable computer users. pp. 481-490.[Online]. Available: http://epubs.scu.edu.au/cgi/viewcontent.cgi?article=1003\&context=edu c_pubs.

[14] Pardjono, dkk. (2003). Pendidikan kejuruan dengan kurikulum berbasis kompetensi berorientasi kecakapan hidup. Makalah disampaikan dalam Lokakarya Pembelajaran dengan KBK Berorientasi Kecakapan Hidup. Yogyakarta, April. 29-30, 2003.

[15] Gage, N.L. A conception of the process of teaching. A Conception of Teaching, Springer Science + Business Media. Chapter 4. 2009. pp. 61-83. DOI: 10.1007/978-0-387-09446-5_4. [Online]. Available: http://ebooks.ohiolink.edu.proxy.lib.ohio-state.edu/. 